\title{
Corruption, Marginality and Social Disorder as Threats to National and Human Security in Nigeria
}

Ujomu, Philip Ogo*

\section{Abstract}

This essay focuses on the issue of corruption, marginality and the social disorder attending it, as threats to national and human security in Nigeria. It not only examines the problems of corruption in Nigeria and the implications of this for national security, but also, discusses the role of an ethical idea of citizenship in tackling corruption and reinventing the political community. In Nigeria, corruption has played a key role in aggravating the political and economic crisis besetting the country. Depreciation of human dignity and collapse of infrastructures have ensured the systematic elite misappropriation of state power, the primitive accumulation of capital, ethno-cultural intolerance and political manipulation in the society. This paper searches for a set of norms capable of mitigating needless

\footnotetext{
* Dept of Philosophy and Religions, Faculty of Arts, University of Benin, Benin-City, Nigeria; pujomu@yahoo.com. Philip Ogo Ujomu teaches Philosophy at the University of Benin, Benin-City and holds BA, MA, and $\mathrm{PhD}$ degrees in Philosophy from the University of Ibadan, Ibadan, Nigeria. The direction of his research combines a very strong commitment to theorizing in Social Science and Humanities with a steady devotion to the mitigation of the African predicament. He is affiliated to a number of learned societies.
} 
dehumanization and inequalities, and improving welfare of the majority by evolving public citizens oriented to the common good.

\section{Introduction and Problem}

The issues of corruption and national security are a matter of urgent concern in Nigeria. The problem as we understand it is to determine the extent to which the problem of corruption in Nigeria has weakened the country's national security, construed as the concern for national survival, national self defense, the preservation of a government's sovereignty or even the broader focus on social justice and the realization of peace and progress for those in society. We argue for the urgent imperative of evolving public citizens oriented to the common good of an ethical community, and we stress the need for a balance between human personal responsibilities and the broader political concern for others, as the basis of social existence in Nigeria. In statistical terms, reports indicate that as far back as the year 2000, not less than the sum of $\$ 98.8$ billion dollars had been illegally stolen and hidden away in foreign banks by various Nigerian rulers, their families and acolytes (Aluko, 2000:13). Decades after that period the corrupt practices have only intensified reaching a peak in the current dispensation. The vitiation of national security in Nigeria has been linked to the dismal lack of vision, poor managerial ability, and the lack of moral integrity of erstwhile regimes in Nigeria. If perhaps, the estimated $\$ 98.8$ billion dollars fraudulently appropriated by some Nigerians, had been diverted to the task of national infrastructural and educational development, then most of the vital social architecture necessary for the establishment and sustenance of national and human security in Nigeria, would have been in place such as efficient education, military, transport and industrial systems. It becomes clear, how the national and human security of a country can be threatened by an economic crisis triggered by corruption among public officials, leading to government's poor resource management ability.

Background: Marginality, Insecurity and Disorder in Nigeria 
The fundamental problems confronting Nigeria have not altered significantly in the past decades. The basic problems have centered on corruption and disorder as threats to unity, security and social justice. There is a national and human security problem in Nigeria, easily seen in the inability of the Nigerian government and the country at large, to ensure the protection of its core values; its territories, infrastructure, officials, citizens, laws and institutions. This has ensured that the various governments and the state agencies have been unable to consistently and institutionally guarantee the adequate protection, peace and well being of the generality of the citizens. The problem of security in the Nigerian nation-state is seen in the fact that the idea of security was reduced to the personal security of the ruler and that of his immediate supporters. These gaps are tied to the logic and consequences of corrupt practices that create conflict. As an empirical account, the House of Representatives Fuel Subsidy Probe Report 2009-2011 (2012:62 \&63) reports that "the mood of the nation is justifiably ill tempered. There is a conflict between the people's larger interest and the self interested clique of government officials seemingly out of tune with the existential realities of the ordinary man in the street. The Nigerian people from all social indicators are already impoverished by the maladministration of the political elite." To put the matter in a clearer perspective, "a large section of the population faulted the premise of the government subsidy figures maintaining that unbridled corruption and an inefficient wasteful process accounted for a large part of the subsidy crisis" (Removal of Fuel Subsidy, Guardian Newspapers. Editorials, pp.62-68).

The problem of disorder is tied to the concerns over crude oil exploration, extraction and subsidies in Nigeria. According to the House of Representatives Fuel Subsidy Probe Report 2009-2011 (2012: 129-130) the Nigerian National Petroleum Corporation "NNPC continued to pressurize officials of other agencies, especially the PPRA to process and pay subsidy on the product...the NNPC and its Ministry merely arrogated to themselves the power to override the Presidential Directive." According to the House of Representatives Fuel Subsidy Probe Report 2009-2011 (2012:131) the "inefficiency of the NNPC, PPMC and Ministry of Petroleum reflected in the failure to supply the product to Nigerians at affordable pricing...to further underscore 
their inefficiency, various agencies gave conflicting retail price of the product in the open market." The House of Representatives Fuel Subsidy Probe Report 2009-2011(2012:74 \& 116) reports that " while the NNPC feasted on the Federation Account to bloat the subsidy payable, some of the Marketers took the option of claiming subsidy on products not supplied. Also the state of our refineries is nothing to write home about as it appears that greed and corruption, etc, among operators in the downstream sector colluded to strangulate the refineries."

We notice clearly a need for a rectification of shortfalls in Nigeria's Dominant Social Paradigm (DSP), of corrupt leadership, warped state centric security, ethno religious conflicts" (Ujomu 2009:21-23). Ajibola (2010:11) argues further that "Nigeria is the most populous nation in Africa, we are deprived of the ordinary basic needs of life as a result of endemic corruption which has now overwhelmed us. Generally the situation of our infrastructure is appalling, at the moment is the state of insecurity. People are being killed with impunity, we are now at the mercy of hoodlums, armed robbers, kidnappers and all these die-hard criminals." (Ajibola in Gyamfi 2010:11). Braithwaithe concurs with the above when he says that "an unprecedented and widespread corruption in governance and injustice have combined to engender insecurities, insurgencies, heightened criminalities, widespread unemployment, all in the face of mindless profligacy of the corrupt" (Braithwiathe 2012:10).

Other recent documents like the CENCOD 2011 annual report (2011:ix-xi) state that "Nigerians still face varying forms of human rights violations. The state is still largely authoritarian as security forces trample on the rights of the citizens with a surprising impunity unexpected in a democracy. There are reports of misappropriation and misapplication of state resources by incumbent state actors" as well as local authorities and foreign business interests. According to the CENCOD 2011 annual report the common people have been driven beyond the poverty threshold "the unemployment rate in the country is alarming. It is perhaps one of the major causes of crimes involving youths such as armed robbery, internet scams, and kidnapping" (CENCOD 2011 annual report 2011:xi). Beyond the general trends there were specific patterns in the trend of social disorder, national insecurity 
and problems of human dignity in Nigeria. According to the CENCOD 2012 annual report (2012:xi-xii)"the harsh economic policies foisted on the people by the ruling elites underpin the rising social violence in the country and were accountable for the upsurge of violence and violations recorded. The Boko Haram sect insurgent activities increased. The northern half of the country became a battle front with waves of suicide bombing and killing of innocent citizens culminating in the total collapse of governance and institutions of government in the affected states."

The pattern of conflict, corruption and disorder shows that there is apparently an absence of a genuine commitment to the values of trust and dialogue as these values have been undermined by poverty, ignorance, ethnic biases and religious extremism. These shortfalls have led to the demands for institutional arrangements for the rectification of injustices and marginalization. Evidently the demands of the numerous aggrieved groups focus on the need for installing elaborate procedures of fair treatment and negotiation which will counter balance the reality of insecurity and marginalization of the various social groups in the physical, political, economic and social realms of life. The economic gap can be seen in the contrasts in nutrition, education, disease patterns, family size and life expectancy (Brown 2008: 107). It is clear that "part of the challenges facing the state in a globalizing world are still classic internal ones, the incomplete construction of nationstate identities; deliver effective services, difficulty of controlling crime and violence. However, financial transactions, microbes and weather patterns do not respect national borders" (Ferguson 2006:7).

Put simply, the institutionalization of corruption has since created problems for the notion of governance and security as well as entrenched the idea of exclusion. Olukoshi and Agbu (1996:94) hold that corruption, has seemingly acquired the status of a directive principle of Nigerian state. According to Joseph (1997:140) every Nigerian government, from the regional administration under colonial role in the 1950's to the Abacha regime has carried corruption to an unparalleled degree. As things stand, corruption has become a bane of development and a major cause of social conflicts (Oyeshile 2000:54-55). The prevalence of corruption is 
linked to the situation which the government or state is responsible for the bulk of all socio economic activities, employment, contracts, etc. Hawthorn (1993:335-336) holds that "so much economic life is dependent on the state". This situation ensures that defrauders of the state are able to exploit administrative lapses in order to benefit illegally. Key agencies often seizes these opportunity created by a weak state to install corruption.

\section{Gaps in Nigeria's Formulation of National and Human Security Policy or Architecture}

Security is important in the life of a person or group. National security is an important concern in the life of a state. The concern for the security of a nation is undoubtedly as old as the nation-state itself (Brown, 1982:21). The central feature in the quest for national security is the concern for national survival (Brennan, 1961:22). However, it can be said that survival is not all there is to security. There is also the focus on the attainment of peace and progress of individuals, groups and the society (Ujomu 2001:176). It must be noted that real or perceived threats to national security "may have an internal or external dimension" and for many less developed countries LDCs, of which Nigeria is one, national security is manifestly endangered by external threats (Deger and West, 1987:3$5)$.

Contrary to the idea of Deger et al mentioned above, it is a strong contention in this essay that the greater threat to Nigeria's security arises from the actions of its citizens, especially the actions of government and some corrupt elite who have through their conduct and beliefs mortgaged the very integrity of this nation and exposed the bulk of the citizens to unnecessary fear, deprivation and chaos. The problem of national security in Nigeria is seen in the serious conflicts that have plagued the Nigerian state since independence. Evidence of this is seen in the continuous ethnic, political, religious and socioeconomic crisis besetting the country. One of the major reasons for this situation of insecurity and instability is that many of the previous national governments applied myopic, perverted and unviable ideas of national security. 
This situation allowed a pervasive trend towards misrepresenting the concept of security. On the one hand it ensured the alienation and subjugation of the citizens from the values and processes that can effectively create a secure socio-political environment. On the other hand, it gave rise to what Amuwo (2000:2) refers to as the government's overriding concern for regime and personal security. In this regard, the security of the Nigerian nation-state was easily and conveniently reduced to the personal security of the ruler and that of his immediate supporters, thus ensuring its lack of logic and effectiveness as a security principle, in a society driven by mistrust, apathy, deprivation and difference. The gap in this regime security formula was that it did not include vital aspects of social and national development such as the provision of basic social amenities (Egwu, 2000:4). The interesting thing is that those who seek to entrench personal security go to almost any extent to appropriate public funds and collective resources to further their own selfish personal ends. This kind of contradiction breeds hate and the horrors of conflict.

A major fallout of this perversion of security was the inefficient and inappropriate functioning of the military and security forces under the faulty realist- statist paradigm, as seen in its entrenched deployment for certain unethical and unconstitutional purposes via brutality, abuse of human rights and lack of due process. The failure of the military in Nigeria to ensure national security is linked to factors such as "acts of social banditry, political involvement, corruption and ethnic manipulation" (Luckham, 1998: 589-592). For instance, the inefficiency of the police force and its failure to maintain law and order and provide security for the citizens has created a vacuum that is being filled by violent, dubious and ill-trained auxiliary ethnic militia, vigilante groups and militant civil society vanguards (CDHR, Annual Report 2000; $\mathrm{x}$ ) and even terrorists, insurgents and cross border (army renegades from Niger republic and rebel groups from Chad) banditry in the northern states of Nigeria. The links between corruption and the crisis of national security in the nation can be seen in the political and economic difficulties arising from both the struggle for state power among the national elite, and the effects of these on the distribution and the management of the society's wealth and resources. The deficiency of a corrupt national elite and its negative 
effects on the country has been recognized by Obasanjo (1999:8) who says that our national life, has been overtaken by confusion, greed, corruption in high and low places, selfishness, pervasive lawlessness and cynicism.

\section{Typologies of Corruption}

What is corruption? Corruption is "the illegal, unethical and unauthorized exploitation of one's political or official position for personal gain or advantage" (Gyekye, 1997: 193). Goldstein (1999:418) notes that corruption is a means of influence. It includes payoffs, kickbacks, gifts, bribery. Other activities classified under corruption are graft, nepotism, misappropriation of public funds, etc. These things do not at all means the same thing and their various meanings have implications for the quest for viable public ethics, and underscore the focus on the ethical regeneration of public officials. For instance, bribery means giving something to somebody in order to influence. Graft means taking wrong advantage of connections in politics. Nepotism involves some person in high places giving special favour to his or her relatives. Misappropriation means to take and use wrongly someone else's money. More importantly, the operations of the white-collar criminal category, comprising persons in business, government, and corporate organizations who violate state and federal statutes, have led to the depreciation of public ethics and public trust. We are especially concerned with the character and motivations of the professional fringe violators are those members of legitimate professions who employ professional skills in the commission of crimes which are not regarded as legitimate activities within the profession. We are also interested in the embezzler type of crime which involves persons who violate positions of trust by stealing from an employer, while ostensibly performing a conventional occupational task (Gibbons, 1965:111-114). These typologies are by no means exhaustive.

Whatever the differences that exist among these corrupt practices, they have similar effects, that center around the vitiation and erosion of social, economic, moral and political life. Political corruption involving public officials is one of the most serious 
problems confronting Nigeria today. The major effects of corruption include the "privatization of politics in so far as this concerns the distribution of benefits from economic transactions [exchange and capital accumulation]" (Goldstein, 1999:574). It makes daily life and business transactions more cumbersome, delaying economic intercourse, boosting costs and diverting energies to the concealment of private gain (Hogendorn, 1996:6465). It leads to the abuse of power (Paden, 1997:261) and 'deteriorating fiscal and economic management, arbitrary policy change, deficit financing, and a chronic, unrecorded leakage of funds' (Lewis, 1997:305 \& 320). Corruption leads to a blurring of the line between private and state property, erodes public trust, invites incompetence and violates the very laws and rules that African states promulgate.

\section{Corruption as a Threat to Governance}

In Nigeria, the inclination to perpetrate corruption has been carefully documented by scholars. Corruption is "the means for the primitive accumulation of capital in Nigeria and this has led to the accentuation of the lust positions of state power" (Iyayi, 2001:122). Government officials ranging from the state leader to the petty bureaucrat have had the power to shape the process of accumulation (Goldstein, 1999:573-574). French (1995:306) says that in Nigeria anyone wanting to do virtually any business there must bribe public officials. Hogendorn (1996:65) states that in Nigeria, a majority of new university graduates applying for federal civil service positions want to join the custom and excise department where bribes are fattest. It is clear then that corruption is pervasive in the Nigerian society. Oyeshile (2000:55) holds that corruption manifests in both the public and private realms of life in the country. The federal government, government agencies, parastatals, the police force, the universities, the companies, the home and even the churches and mosques are not exempt. Furthermore, Taiwo (1996:265) holds that the ultimate in Nigerian business achievement is to become a "manufacturer's representative for a Western principal. Many rich men in Nigeria have no other means of production beside their political connections or their business cards. 
This trend has prevailed in Nigeria since independence. The point must be made that people mainly seek state power not because they wish to make a contribution to the common good or to improve the well-being of all in the society, but because they want to satisfy their greed and oppressive tendencies. The power they exercise make them prone to corruption most especially, since they lack the intellectual and moral basis for the proper utilization of this power for the good of all. Indeed, most of Nigeria's corrupt civilian and military regimes "have pushed predatory accumulation to an unsustainable level" (Luckham, 1998:29), leading to endemic crisis of social order and insecurity in the country.

Corruption among individuals is occasioned by vices such as avarice and profligacy. Thompson (1987:11) holds that public officials commit immoral deeds out of greed, the desire for power or loyalty to family and friends. This raises vital questions about the moral status of the person and the quality of his or her character. Corruption, which is rampant among the wealthy, influential or well placed individuals in Nigeria, can be due to lack of decorum, decency and transparency in governance. The situation may be such that even if one did not need to be fraudulent, yet such a person would engage in corruption, simply because those institutions and structures which can uphold and maintain accountability, responsibility and transparency, either do not exist, or they are ineffective. Thus, the absence of the necessary checks and balances against corrupt and fraudulent practices among individuals can create a situation in which the various productive sectors of a society are endemically mismanaged.

It is instructive to note the claims by different geopolitical regions of Nigeria that they have been deprived and marginalized, the general collapse and predation of physical infrastructures and the demands for a national conference and resource control are all evidence of the lack of sustainability and moral worth of the process of corruption and predation in the country. The effects of corruption on social and economic deprivation, anomie and political instability are evidence of the "delegitimising political effects of primitive accumulation" (Olukoshi and Agbu, 1996:94). The disaffection occasioned by corrupt practices can be linked to 
the fact that 'officials violate the rights of citizens with impunity by acquiring wealth at the expense of the public' Sklar (1997:33). The control over state power grants people access to the private expropriation of large amounts of national resources (Iyayi, 2001:122). The fact that the revenues were not effectively used in the quest for socioeconomic development, has led to greater poverty in the land. Indeed, 'the unequal distribution of wealth' (Ingham, 1990:65) among the different sectors in the society, ensured that the revenues from oil products did not have positive and enduring impact on the lives of the generality of the Nigerian peoples. Rather, as Calvocoress (1997:614) observes, the 'rich merely got richer while the poor remained poor or eventually got poorer'.

\section{Corruption as a Threat to Security}

Corruption plays a negative role in the maintenance of national security irrespective of the way we choose to conceive it. It we construe national security as the protection of national survival, then it may either be seen as the desire and capacity for national self-defense (Ray, 1987:248-249) or the preservation of the borders of a state and the power to maintain a government's sovereignty within its territory (Goldstein, 1999:79). In short national security will be variously seen as the confrontation of threats to peace in the society (Hare, 1973:86-89) or the avoidance of conflicts, and the preservation of the lives of people in the society (Africa Research Bulletin, 2000:13931-55).

It has been assumed that some corrupt individuals or organizations can vitiate government's attempt to entrench national and human security. Thus Kolderie (1987:48) suggests that government will have to be a smart buyer and be more careful, if it is to avoid creaming and corruption among private contractors and public bureau who tend to avoid difficult work. Although Kolderie is right to argue that government should carefully specify and inspect the work it wants done, yet Kolderie does not realize that in Nigeria, it is usually people who are in government that engage in the worst forms of corruption. The more urgent question then is how to deal with public officials who engage in corruption? 
A government that cannot effectively enforce its civic charter and promote the public good is weak and a danger to itself and the geniality of the citizens. Corruption sustains or continues inequalities and reproduces existing patterns of privilege (Fatton, 1992:84). Worse still, corruption ensures that contracts and appointments are not got on the basis of desert, thus discouraging honest effort. It leads to distrust for the motives of others, and undermines the credibility of those in positions of power. It breeds resistance to authority and compels officials to misdirect scarce resources to low priority sectors (Elegido, 1996:245-246).

These resources that have been corruptly acquired and misused would have otherwise been used to make the lives of the citizens more meaningful. The endemic corruption of past governments and public officials ensured that effective planning and execution of national development plans could not be attained. Consequently, adequate plans for infrastructural development such as, the provision and maintenance of good road networks, schools, pipeborne water supply, electricity, etc, were neither carefully set out, nor achieved (Simpson, 1996:191). Visible and incontrovertible evidence of corruption can be seen in the collapse of various public institutions. The unmitigated and relentless acts of corruption within the Nigerian society, have led to a plethora of badly functioning medical and educational systems, poorly maintained road networks (Diamond, 1995:437) and porous air and sea ports among others. It is clear that the collapse of infrastructures and the rising phenomenon of insecurity prevailing within the nation are the effects of corruption.

The Political Logic and Architecture of Corruption: The Egoism of Public Officials and the Predation of Elite Political Economy

The discussion on corruption can be linked to the internal contradictions of inequity, segregations and false humanism in the process of elite formation and consolidation, and the relayed effects of this phenomenon on the construction of social order. Politics in Nigeria connotes the acquisition of wealth by corrupt practices. Politicians were willing to obtain power at all cost, since the control of power emphasized the control of the economic strings of the society (Nzimiro, (1984:36-37). Ake (1996:15) is right when he says that "a society of beggars, parasites and bandits cannot develop, it 
cannot know peace or stability and it cannot be democratic. It can only gravitate endlessly in material poverty and moral regression". The devastating effect of corruption in government, (Diamond, 1995:438) is linked to the misuse of state power by the different ethnic elite, public servants and bureaucrats. Lewis (1996:100) holds that post-independent Nigeria has been characterized by the widespread appropriation of nominally public resources for personal or parochial gain. For instance, as far back as January 15, 1966, a Nigerian Army Officer Major Nzeogwu claimed that the aim of his coup d'etat was to "create a free country, devoid of corruption, nepotism, tribalism and regionalism" (Uwechue, 1991:1459).

The Nigerian society has over the ages, been saddled with a confused, fractionalized and extremely corrupt elite, lacking a viable production base and who rely heavily on institutional and private mechanisms of violence and social-cultural manipulation to maintain political dominance (Ihonvbere, 2000:74). The state provides for these elites access to markets and illegal activities (Castells, 1998:103) through which they can consolidate the opportunities for rent, corruption and embezzlement (Fatton, 1992:59). This has further created greater conditions of inequality in the society. Looking at this problems from a historical perspective Graf (1983:190-193) states that Nigerian elites have been a faulted bourgeoisie, because their socio-economic position and values were shaped by the colonial experience. The Nigerian bourgeoisie was essentially a non-productive successor elite to the colonials, continuing the tradition that focused on the state as a primary source of elite formation and consolidation. Hence, the possession of political power was seen to be a guarantee of security, wealth and honours. The wealth of the elite was a derivative of which positions they occupied in government, and how much access to state power and patronage accruing from these (Fatton, 1992:59).

The reason for the 'lack of production and communications infrastructure, lack of human capital" (Castells, 1998:90-91) is the misuse of valuable resources and international aid by the elite. This is the brain-child of a rapacious bourgeoisie class that exhibits an unprecedented level of mediocrity and immorality (Fanon, 1983:135). Their aim is to solidify their status and wealth, which 
they transfer to their children, thus crystallizing the disparities in wealth (Fatton, 1992:59) in the society and engendering conflicts and chaos. This closure of class mobility, as well as the dichotomisation and antagonisms arising thereof, leads to provocations arising from the "vulgar life styles of government functionaries" (Biersteker and Lewis, 1997:316). It also leads to regional and ethnic rivalries and instability (Kemp, 1998: 184 \& 188), inefficiency and lawlessness (Calvocoress, 1997:615), alienation and conflicts (Barongo, 1983:140).

The Economic Logic and Architecture of Corruption: The Rentier State and A Culture of Patrimonialism

The actions of the elite can be interwoven with the emergence and operations of a predatory state which primitively excludes so many stake holders causing poverty and inequality on a massive unsustainable scale. Philips (1996:300) holds that an environment may be so corrupt that the level of official compliance to duty is very low, and payoffs are so widespread that they are virtually institutionalized. The Nigerian state is a patrimonial and rentier one in which those who are in control of state power and strategic bureaucratic offices use their positions for private appropriation. In the patrimonial administration there is an amalgamation of the private and public domains. Political administration is treated as a purely personal affair of the ruler, and political power is considered part of his personal property (Ibrahim, 1997:156).The patrimonial state does not feel the need to promote the common good and its logic is essentially limited to the distribution of prebendal offices and to the reduction of the access of the people to power wielders.

A rentier economy is one that retires on substantial external rent or a reward for ownership of all natural resources (Ibrahim, 1997:157). This type of state breeds a cruel kind of citizens retaining a lack of patriotism to the nation, and who uphold selfish interests over the interests of all. These are 'people who lack moral integrity' (Jois, 1988:16) and are specialists in the abuse of laws intended for the public good and meant to ensure social justice. They take pride in the exploitation of the weak and vulnerable members of society and triumph in the performance of all sorts of despicable malpractices. Nothing is beyond these types of people, including 14 
stealing the subsistence funds meant for the payment of the pensions of the aged retired workers in the Nigerian society, stealing the severance funds meant for rehabilitating Nigeria's exmilitary and Police service veterans, diverting funds meant for the construction of social infrastructure provided for the common good and even stealing maintenance funds meant for feeding children in primary and secondary schools.

The concentration of unaccountable power in the hands of a privileged minority in the patrimonial state, ensures that the majority are effectively disenfranchised, and that few if any can contribute meaningfully to national development. The pattern of political leadership in Nigeria has compelled scholars to describe them as typical of a predatory state. This type of state employs the paradigm of governance referred to as prebendalism and kleptocracy, which are inextricably linked to the power to appropriate resources and the minimization of the number of beneficiaries (Dommen, 1997:491). Castells (1998:96-102) holds that the misuse of capital have characterized the predatory state or 'vampire state' which is essentially, a state entirely patrimonialized by political elites for their own personal profit. The predatory state is characterized by both prebendalism and predation understood as political patronage, systematic government corruption, concentration of power at the top and the personalization of networks for the delegation of this power. These tendencies are prevalent in Nigerian politics. Hawthorn (1993:336) points out that within such a framework, the elite have deployed their positions within what remains the directive and authoritative frames of postcolonial states. The decadent patrimonial state having civilian or military rulers, has celebrated the abuse of power and the endorsement of antidemocratic values, political violence and intolerance in politics (Diamond, 1988:12-14). These rulers have been aided by the presence of ignorant, illiterate, apathetic and uneducated populations, as well as indigenous cultural traditions that tended to underwrite authoritarianism and anachronism. 


\section{Political Morality, Social Justice in Government: Good Governance as an Option for Change}

What is the way forward? The state and its officials need to be effective for the reasons stated below: Edelman (1975:14) rightly holds that large numbers of people depend on government for protection from a wide spectrum of dangers such as foreign threat, criminal threat, fuel and food shortage. All the above features are illustrative of what the government seeks to achieve, and aspires towards as the common good. The idea of the "common good" is 'attached to objects and policies that are beneficial to the whole taken collectively' (Schochet, 1979:24). If government is to be seen as a rational device for satisfying people's needs, then it must be capable of proper operation, using the rules of good governance. Leftwich (1993:610-611) holds that the underlying features of good governance include, the accountable administration of public funds, an independent public auditor, an efficient public service, among others. The requirements of good governance, which are embodied in the official acts of social responsibility raises issues that are the core of moral and political philosophy. It raises fundamental questions about our idea of citizenship, our interests, our duties and commitments. It examines the character of our behaviour especially where our actions will have an impact upon the interests, needs and entitlements of others.

The issue then is to link our actions as citizens and public officials, and several areas of the demand for security, such as internal security, nation building, and secure systems of food supply (Thomas, 1987:1). How then do we overcome the difficulties arising from the insecurity, lack of autonomy and vulnerability emanating from the problem of perverted citizenship or corruption that we see among public officials? In a significant way the question of entitlement arises. According to Deger and Sen (1987:84-85) entitlement refers to the "set of alternative commonly bundles that a person can command in a society using the totality of rights and opportunities available, for instance, the individual's endowment, available private and public goods and services, as security, freedom and human rights. Rothstein (1987:143) holds that the state must meet the growing demand for internal 
development by choosing a strategy that does not undermine harmony, actualization, effectiveness and stability.

The urgent and central question can be posed as to whether African governments will be capable of establishing 'developmental states' that respect their budget constraints, allocate resources, pursue policies that develop human resources and encourage privatesector saving and investment to generate productive employment and promote growth? (Ndulu and O'Connell, 1999:52-53). This question is not as direct or explicit as Ndulu et al have posed it. It implies two types of concerns. First, there is the issue of whether African governments have the kind of technocratic capability and skills necessary for such a developmental state? Second, there is the concern of whether given the presence of such skills and knowledge the African governments have the right sort of attitudes and values required for the effective conversion of these skills? To put it more concretely, the question is whether in African governments, we have people who have a sustainable orientation and training of ethical citizenship needed to mitigate the negative effects of inequality poverty and misery?

According to Gibbons (1965:271) dealing with all sorts of perpetrators of political and economic corruption including whitecollar offenders, requires vigorous and consistent law enforcement. This implies that detected law violators need to be dealt with according to the rule of law by the criminal courts. Attempts need to be made to generate a code of ethics among organizations that stress scrupulous fidelity to the law. Nigeria has a Code of Conduct bureau that requests public officials to declare their assets upon assuming public office and periodically thereafter. Is this strategy really effective, given that people under-declare their assets and a lot of income earners are not in the public sector working for government? There is a need to prevent re-employment of corrupt persons, in situations where additional embezzlement could occur. Individuals can acquire an official record or a kind of profiling that will enable them to be identified and contained. This requires massive financial and moral investments in record keeping and ICT access and infrastructure. Does the nation have the political will and ethical propensity to embark on this task given that the law breakers are actually those with access to power and resources to 
subvert the law and escape justice? While these are clearly good and effective ways of confronting the challenge of corrupt public officials, there is a need to reclaim the ethical dimensions or perspectives of the problem.

This point is significant when we look at what Castells (1998:71) refers to as the domain of relationship of distribution and consumption or differential appropriation of the wealth generated by collective effort. The challenge of ethical citizenship is reflected in the consistent attempt to overcome social exclusion, defined as the process by which certain individuals and groups are systematically barred from access to positions that would enable them to an autonomous livelihood. Our concern then is to evolve a political culture that can install and sustain political attitudes and values that are conducive to harmony, cooperation and stability (Cammack, 1997:92). In this regard the lessons of an ethical conception of public or official action cannot be overlooked. Larmer (1996: xi \& 2) holds that we cannot safely ignore the principles of ethics, since we are all faced with ethical decisions, which prescribe how people should act. This is an indication of the fact that there are moral constraints on human interaction which involves limitations on our right to benefit at the expense of another or rather which essentially involves a constraint on individual pursuit of their well-being (Beversluis, 1996:11-16). These are the moral qualities that we need to imbue or instill in the individuals who will carry on the quality of citizenship that will guide our lives.

The way by which we can achieve public trust and public ethics in governance, includes, teaching and emphasizing right and wrong through moral rules. It can also be done through the express determination of minimum and positive standards that everyone should follow (Davis, 1990:30-31). However, Davis (1990:35) points out that good conduct presupposes both good will with its underlay of good character and knowledge. Norton (1996:47) holds that the concern for the development of moral character does not altogether neglect rules, but views them instrumentally with reference to that end. This issue of good character is very important because as French (1995:3) says, we are in a world of moral ambiguities and confusions where duties are not as clear as before, especially in the face of scarcity and all manners of outlooks 
or influences. To the extent that activity is rule governed, we can separate 'good' from 'bad', or right from wrong. The thrust is to make law abiding behaviour the basis of political obligation among the rulers, elites and citizens. Behaving according to the rule of law ought to be a duty of perfect obligation something that can be demanded from the leaders as a moral obligation.

\section{Conclusion}

Finally, we focused on the issue of corruption and social disorder as threats to national security in Nigeria. We examined the problems of corruption in Nigeria and the implications of this for national security and discussed the role of ethics and law enforcement in tackling corruption. We saw that corruption in Nigeria weakened the country's national and human security, construed as the concern for national survival, national self defense, the preservation of government's sovereignty and peace and well being of the citizens. We sought for peace in society and sought to evolve public citizens oriented to the common good of an ethical community. We stressed the need for a balance between human personal responsibilities and the broader political concern for the public interest as the basis of social existence in Nigeria.

\section{References}

Ake, Claude. Is Africa Democratizing? Port Harcourt: Center for Advanced Social Science. CASS. Monograph no. 5, 1996.

Aluko, Bolaji. “Our debt, Their Loot" The News. June, 2000.

Amuwo, Kunle. "The Discourse of Political Elites on Higher Education in Nigeria" Y. Lebeau et al. The Dilemma of Postcolonial Universities. Ibadan: Institute of French Research in Africa IFRA/African Book Builders, (2000): 1-26.

Attfield, Robin. Environmental Ethics. Polity Press, Cambridge, U.K, 2003.

Barry, Brian. 'Sustainability and Intergenerational Justice'. Theoria, 45(89), June, 43-64.1997. 
----. 'Circumstances of Justice and Future Generations'. Obligations to Future Generations, Cambridge: White Horse Press, 204-48, 1996.

Beckermen, Wilfred. 'Sustainable Development and our Obligations to Future Generations', in Andrew Dobson (ed.). Fairness and Futurity: Essays on Environmental Sustainability and Social Justice, Chapter 3, Oxford: Oxford University Press, 71-92, 287-91,1999.

Beversluis, Eric "Is There No such Thing as Business Ethics". R. Larmer (ed). Ethics in the Workplace Selected Readings in Business EthicsCanada:Minneapolis West Publishing Company, (1996): 1116.

Biersteker, Thomas and Peter B. Lewis "The Rise and Fall of Structural Adjustment in Nigeria" in L. Diamond et al, edited. Transition Without End London: Lynne Renner. (1997): 303-331.

Braithwiathe Tunji. "Corruption, the bane of the nations ills" The Guardian Newspapers. Monday. October 1, (2012): 10.

Brennan, Donald 'Setting the goals of arms control" in D.G. Brennan Ed. Arms Control, Disarmament and National Security. New York: George Brazillier, (1962): 19-42.

Brown, Lester . "An untraditional view of national security" in Reichart. Ed. American Defense Policy. Baltimore: John Hopkins University press, 1982.

----. Plan B 3.0 mobilizing to save civilization. New York: W.W. Norton and $\mathrm{Co}, 2008$.

Burton, David. 'Buddhism', The Routledge Companion to the Philosophy of Religion, London: Routledge, in Chad Meister and Paul Copan (eds) (2007): 16-27.

Calvocoress, Peter. World Politics $7^{\text {th }}$ edition. London: Longman, 1997.

Cammack, Paul. Capitalism and Democracy in the Third World: The Doctrine for Political Development. London: Leicester University Press, 1997.

Castells, Manuel (1998) The Information Age: Economy: Society and Culture Volume 111. End of Millennium Massachusetts: Blackwell.

Center for Constitutionalism and Demilitarization CENCOD 2011 Annual Report (2011) State of Human Rights in Nigeria. Lagos: CENCOD. 
Center for Constitutionalism and Demilitarization CENCOD 2012 Annual Report (2012) State of Human Rights in Nigeria. Lagos: CENCOD.

Committee for the Defence of Human Rights (CDHR) (2000) 1999 Annual Report on the Human Rights Situations in Nigeria. Lagos: CDHR.

Committee for the Defence of Human Rights (CDHR) (2001) 2000 Annual Report on the Human Rights Situation in Nigeria. Lagos: CDHR.

Davis, Michael. "Who can Teach Workplace Ethics?" Teaching Philosophy. Vol. 13. No 1 (March, 1990): 21-38.

Davis, Michael "Explaining Wrongdoing" R. Larmer. Edited. Ethics in the Workplace: Selected Readings in Business Ethics. Minneapolis: West Publishing Company, (1996): 17-27.

Deger, Saadet and West Robert. Defence, Security and Development. Edited. London: Frances Pinter, 1987.

Deger, Saadet and West Robert "Introduction defence expenditure, national security and economic development in the third world". in S. Deger and R. West. edited Defence, Security and Development. London: Frances Pinter, 1987. 83-101.

Diamond, Larry. "Introduction: Roots of Failure, Seeds of Hope" in Diamond et al (ed) Democracy in Developing countries: Africa volume 2 (Colorado: Lynne Rienner). (1988): 1-31.

----.., "Nigeria: Pluralism, Statism and The Struggle for Democracy" in Diamond et al (ed) Democracy in Developing countries: Africa volume 2 (Boulder-Colorado Lynne Rienner). (1988): 33-91.

---- "Nigeria: The Uncivic society and the descent into Praetorianism" in L. Diamond et al (eds.) Politics in Developing Countries Comparing Experience with Democracy. (Boulder. Lynne Renner) (1995): 417 191.

Dommen, Edward. "Paradigms of Governance and Exclusion" The Journal of Modern African Studies. Vol. 35. No. 3. (1997): 485-494.

Doniger, Wendy O'Flaherty. Karma and Rebirth in Classical Indian Tradition, Motilal Banarasidas, 1999.

Edelman, Murray. "Language, Myths and Rhetoric" Society (July/August) 1975. 41-21. 
Editors ARB, "Nigeria" Africa Research Bulletin ARB. April, 2000.

Egwu, Samuel. "The Origin, Nature and Politics of The Niger-Delta Crisis: The consequences of violence on the future of Youths" A paper presented at a Workshop on the reorientation of Youths/Students for the Cause of Peace and Democratic Stability in the Niger-Delta. Akwa-Ibom. Uyo. May, 2000.

Elegido, J.M. Fundamentals of Business Ethics. Ibadan: Spectrum, 1996.

Elliot, Robert. 'The Rights of Future People'. Journal of Applied Philosophy, 6 (2), 159-169, 1989.

Fanon, Frantz. The Wretched of the Earth. translated. C. Farrington. Middlesex: Penguin, 1983.

Fatton, Robert. Predatory Rule: State and Civil Society in Africa. Boulder: Lynne Rienner, 1992.

Ferguson Yale H. "The crisis of the state in a globalizing world" Globalizations. Vol.3. no.1. (2006): 5-8.

French Peter. Corporate Ethics. Florida: Harcourt Brace, 1995.

Gibbons, Don. Changing The Lawbreaker. New Jersey: Prentice-Hall, 1995.

Goldstein, Joshua. "The Contradiction in Ethical Egoism" R. Larmer (ed) Ethics in the Workplace: Selected Readings in Business Ethics. Minneapolis: West Publishing Company. (1996): 36-37.

Goldstein Joshua. International Relations $3^{\text {rd }}$ edition. New York: Longman Addison Wesley, 1999.

Graf William. "African Elite Theories and Nigerian Elite Consolidation: A Political Economic Analysis" in Y. Barongo. edited Political Science in Africa. London: Zed. (1983): 189-210.

Gyamfi Charles Coffie. "Our story of social and economic breakdown by Ajibola" The Guardian Newspapers. Friday. October, 2010): 11.

Gyekye Kwame. Tradition and Modernity. New York: Oxford University Press, 1997.

Hare R. M. Applications of Moral philosophy. Los Angeles: University of California press, 1973.

Hawthorn Geoffrey. "Sub-Saharan Africa" in D. Held. edited. Prospects for Democracy. Cambridge: Polity Press. (1993): 330-354. 
Hick, John, "Religious Pluralism", Charles Taliaferro and Paul J. Griffiths eds., Philosophy of Religion: An Anthology, Blackwell, 2003.

Hogendorn Jan. Economic Development. New York: Harper Collins, 1996.

House of Representatives Fuel Subsidy Probe Report 2009-2011 (2012) "House of Representatives Fuel Subsidy Probe Report (2009-2011)" The Constitution. Vol. 12. No.3. September. Pp.129-156.

House of Representatives Fuel Subsidy Probe Report 2009-2011 (2012) "House of Representatives Fuel Subsidy Probe Report (2009-2011)" The Constitution. Vol. 12. No.4. December. Pp.70-116.

Ihonvbere Julius. "A Recipe for Perpetual crises: The Nigerian State and the Niger Delta Question" in CDHR edited. Boiling Point: A Cdhr Publication on The Crises in The Oil Producing Communities in Nigeria. Lagos: CDHR. (2000): 73-109.

Ingham Kenneth. Politics in Modern Africa: The Uneven tribal dimension. London: Routledge, 1990.

Iyayi Festus. "Human rights practices in tertiary institutions: Reality, prospects

and obstacles" in CDHR Nigeria's tertiary Institutions and Human Rights. Lagos:

Committee For The Defence Of Human Rights Publication, 2001.

Jayatilleka,K.N. Survival and Karma in Buddhist Perspective, Buddhist Public Society, Online Edition, 2008, accessed on 10th April 2012.

Joseph Richard "Democratization under Military Rule and Repression in Nigeria" in P. Beckett and C. Young. Edited. Dilemmas of Democracy in Nigeria. Rochester: University of Rochester Press. (1997): 137-153.

Kavka, Gregory.S. 'The Paradox of Future Individuals', Philosophy and Public Affairs, 11(2), Spring, (1982): 93-112.

Kemp Tom . Industrialization in The Non-Western World 2nd edition. England: Longman Group, 1998.

Kolderie Ted. "What do we mean by Privatization?" Society. September/October. (1987): 46-51.

Krishan Yuvraj,. The Doctrine of Karma In Origin and Development in the Brahmanical, Buddhist and Jaina traditions, Motilal Banarasidas, 1997. 
Larmer Robert . "Introduction: Philosophy, Ethics and Business" in R. Larmer edited. Ethics in the Workplace: Selected Readings in Business Ethics. Minneapolis: West Publishing Company. (1996): ix - xi.

Leftwich Adrian "Governance, democracy and development in the Third World". Third World Quarterly. Vol. 14. No. 3. (1993): 605 624.

Lewis Peter. "From Prebendalism to Predation Political Economy of Decline in Nigeria" The Journal of Modern African Studies. Vol. 34. No. 1 (1996): 79-103.

----., "Politics and the Economy: a downward spiral" in P. Beckett and C. Young. edited. Dilemmas of Democracy in Nigeria. Rochester: University of Rochester Press. (1997): 303-326

Luckham Robin. "The Military, Militarization and Democratization in Africa: A Survey of literature and Issues" in E. Hutchful and A. Bathily. Ed. The Military and Militarism in Africa. Senegal: ODESRIA. (1998): 1-45.

Luckham Robin . "Taming the monster: Democratization and Demilitarization" in E. Hutchful et al edited. The Military and Militarism in Africa. Senegal: CODESRIA. Pp. 589-597.

Masih, Y. A Critical History of Western Philosophy, Motilal Banarasidas, (1998): 388.

Nickel, James. W and Viola, Eduardo. 'Integrating Environmentalism and Human Rights'. Environmental Ethics, edited by Andrew Light and Holmes Rolston III, Blackwell Publishers, (2003): 472-477.

Ndulu Benno. J. and O'Connell Stephen A. (1999) “Governance and Growth in Sub-Saharan Africa" Journal of Economic Perspectives. Vol.13. no.3. Summer. Pp.41-66.

Norton David. "Moral Minimalism and the Development of Moral Character" in R. Larmer edited. Ethics in the Workplace: Selected Readings in Business Ethics. Minneapolis: West Publishing Company. (1996): 47-57.

Nzimiro Ikenna. Nigerian Civil War A study in class conflict. Enugu: Frontline publishers, 1984.

Obasanjo Olusegun. "Moral Foundations for our Polity" The Guardian newspaper (Friday, October 1, 1999) 
Olukoshi Adebayo and Agbu Osita "The Deepening crisis of Nigerian Federalism and the future o the Nation-state" in A. Olukoshi and L Laakso. edited. Challenges To The Nation-state in Africa. Sweden: Nordiska Afrikainstitutet. (1996): 74-99.

O'Neill, John. 'Future Generations: Present Harms'. Philosophy, 68(264), (April, 1993): 35-51.

Oyeshile Olatunji. "Corruption and underdevelopment in Nigeria" Recall: A chronicle of Nigerian events. Number 1. January, (2000).

Paden John. "Nigeria Unity and the Tensions of Democracy: Geocultural zones and north-south legacies" in P. Beckett and C. Young. edited. Dilemmas of Democracy in Nigeria. Rochester: University of Rochester Press. (1997): 243-264.

Parfit, Derek. 'Future Generations: Further Problems'. Philosophy and Public Affairs, 11(2), Spring, (1982): 113-72.

Philips Michael. "Bribery" in R. Larmer edited. Ethics in the Workplace: Selected Readings in Business Ethics. Minneapolis: West Publishing Company. (1996): 294-305.

Radhakrishnan, Indian Philosophy Volumes 1 and 2. London: George Allen and Unwin Ltd. New York: Humanities Press INC. 1977 (reprint). 33

Ray James. Global Politics 3rd edition. Boston: Houghton Mifflin, 1987.

Removal of Fuel Subsidy. The Constitution. Vol. 12.culled form the Guardian Newspapers. Editorials of January 9, 10, 11. Lagos, Nigeria. Vol. 12. No.4. December. Pp.62-68.

Rothstein Robert. "National Security domestic resources constraints and elite choices in the Third World" in S. Deger and R. West. Edited. Defence, Security and Development. London: Frances Pinter. (1987): $140-158$.

Sayadaw Pa Auk Tawya, The Workings of Kamma, Helicon Publishing and Penguin Books Ltd:1996.

Schochet, Gordon. "Social Responsibility, Profits and the Public Interest" Society. March/ April. (1979): 20-26.

Shalit, Avner de. 'Community and the Rights of Future Generations: A Reply to Robert Elliot'. Journal of Applied Philosophy, 9(1), (1992): 105-15. 
----... Why Posterity Matters Environmental Policies and Future Generations. London: Routledge, 1995.

Sharma, I.C and Daugert, Stanley M.E, Six Ethical Ways of Knowing, London: George Allen and Unwin U.K, 1965.

Sklar Richard "Crises and Transitions in the Political History of Independent Nigeria "in P. Beckett and C. Young. edited. Dilemmas of Democracy in Nigeria. Rochester: University of Rochester Press. (1997): 15-44.

Smith, Patrick Nowell. "Morality Religious and Secular", The Rationalist Annual, London: Pemberton Publishing Co. Ltd., 1961.

Taiwo Olufemi "On The Misadventures of National Consciousness: A Retrospect on Frantz Gift of Prophecy" in L. Gordon et al. edited. Fanon: A Critical Reader. Oxford: Blackwell. (1996): 255-270.

Thomas Caroline. In search of Security: The Third World in International Relations. Colorado: Rienner, 1987.

Thompson, Dennis. Political Ethics and Public Office. Cambridge. Harvard University Press, 1987.

Ujomu Philip. "Cultural Relations on, Human Communication and the Conditions for intercultural relations: A critique of Anta Diop and Kwasi Wiredu" in H. Igboanusi. Edited. Language Attitude and Language Conflict in West Africa. Ibadan: Enicrownfit, 2001.

---., "Nigeria's national security problematic and the reinvention of social order: some aesthetic considerations" The Constitution. Vol.9. no.1. March, 2009): 21-37.

Uwechue Ralph. Ed. Africa Today. London: Africa Books, 1991. 